\title{
Correlation between glass transition effect and structural changes in multicomponent iron phosphate-silicate glasses
}

\author{
Justyna Kuczek ${ }^{1} \cdot$ Piotr Jeleń $^{1} \cdot$ Justyna Sułowska ${ }^{1} \cdot$ Magdalena Szumera $^{1}$
}

Received: 15 October 2018/Accepted: 9 June 2019/Published online: 21 June 2019

(C) The Author(s) 2019

\begin{abstract}
Iron phosphate-silicate glasses from $\mathrm{P}_{2} \mathrm{O}_{5}-\mathrm{SiO}_{2}-\mathrm{K}_{2} \mathrm{O}-\mathrm{MgO}-\mathrm{CaO}-\mathrm{Fe}_{2} \mathrm{O}_{3}$ system were subjected to the thermal and spectroscopic studies in order to gain information about their structure and thermal behavior in the range of glass transition effect. Research includes results obtained via DSC, MIR and DRIFT spectroscopy. Designated values of glass transition temperature and specific heat change slightly increases with $\mathrm{Fe}_{2} \mathrm{O}_{3}$ incorporation. Spectra collected during thermal treatment of glasses containing 2 and 30 mol\% $\mathrm{Fe}_{2} \mathrm{O}_{3}$ exhibited various changes. $\mathrm{Fe}_{2} \mathrm{O}_{3}$ addition affected the glass structure by its reinforcement and led to its preservation during thermal treatment. The connection between density, molar volume, oxygen packing density and the chemical composition's alteration were also established because of the direct dependence of physical properties and the structure. Obtained results supported thermal and spectroscopic studies. Conducted research is considered as a contribution to the knowledge about the family of iron phosphate glasses, which are known from their interesting properties and widely used applications.
\end{abstract}

Keywords Iron phosphate-silicate glasses · FTIR spectroscopy · DRIFT · DSC

\section{Introduction}

Iron phosphate glasses present outstanding properties enabling them to be used in various applications [1-13]. As an example, the great storage capacity of high wastes manifested by traditional iron phosphate glasses characterized by molar composition $60 \mathrm{P}_{2} \mathrm{O}_{5}-40 \mathrm{Fe}_{2} \mathrm{O}_{3}$ may be mentioned [14]. Concomitantly, little is known about iron phosphate X-ray amorphous materials containing also silicate, potassium, magnesium and calcium ions. These are considered as eco-friendly and can be potentially implemented into the soil without causing any harm in natural environment. It also needs to be mentioned that the additional components incorporation presumably impacts on iron phosphate glasses properties, such as chemical

Justyna Kuczek

jkuczek@agh.edu.pl

$\triangle$ Magdalena Szumera

mszumera@agh.edu.pl

1 Faculty of Material Science and Ceramics, AGH University of Science and Technology, Al. Mickiewicza 30, 30-059 Kraków, Poland stability and durability, electric and magnetic properties, response to thermal treatment. This effect has never been studied. Thus, there is a lack of information about good qualities exhibited by glasses from $\mathrm{P}_{2} \mathrm{O}_{5}-\mathrm{SiO}_{2}-\mathrm{K}_{2} \mathrm{O}-$ $\mathrm{MgO}-\mathrm{CaO}-\mathrm{Fe}_{2} \mathrm{O}_{3}$ system. The research conducted to evaluate the influence of additives on phosphate glasses allows to gain invaluable information. It also entails the possibility to tailor the materials properties and discover their new applications. Presented work is a contribution which enables to increase the knowledge about iron phosphate glasses family.

Iron phosphate glasses are commonly characterized by $\mathrm{O} / \mathrm{P}$ ratio indicating whether orthophosphate, pyrophosphate or metaphosphate units prevail in the structure [15] which also is verifiable via Raman and infrared spectroscopic studies. It is also agreed that the type of additives and their quantitative proportions determine various material properties. Amorphous materials from $\mathrm{Fe}_{2} \mathrm{O}_{3}-$ $\mathrm{P}_{2} \mathrm{O}_{5}-\mathrm{R}_{\mathrm{n}} \mathrm{O}_{\mathrm{m}}$ system where $n=0,1, m=0,2$ and $R=\mathrm{Si}$, $\mathrm{K}, \mathrm{Ca}, \mathrm{Mg}$ were found to be analyzed in cited papers [14, 16-18].

Designated value of glass transition temperature $\left(T_{\mathrm{g}}\right)$ revealed in iron phosphate glasses with $\mathrm{O} / \mathrm{P}$ ratio $\sim 3.5$ 
modified by incorporation of $5 \mathrm{~mol} \% \mathrm{SiO}_{2}$ is slightly increased compared to the parent glass [14] and it constitutes $508{ }^{\circ} \mathrm{C}$. Results obtained in [16] indicated that in ternary glass system $\mathrm{Fe}_{2} \mathrm{O}_{3}-\mathrm{P}_{2} \mathrm{O}_{5}-\mathrm{K}_{2} \mathrm{O}$, substitution of $\mathrm{Fe}_{2} \mathrm{O}_{3}$ with $\mathrm{K}_{2} \mathrm{O}$ leads to decrease of $T_{\mathrm{g}}$. Authors have designated it as approx. $340{ }^{\circ} \mathrm{C}$ for potassium phosphate glass containing $11.5 \mathrm{~mol} \% \quad \mathrm{Fe}_{2} \mathrm{O}_{3}$ and characterized by $\mathrm{O} / \mathrm{P} \sim 3.1$ [16]. Along with $\mathrm{CaO}$ addition in $x \mathrm{CaO}-$ $(32-x) \mathrm{Fe}_{2} \mathrm{O}_{3}-68 \mathrm{P}_{2} \mathrm{O}_{5}$ glass variation of $T_{\mathrm{g}}$ value is more complex: it rises from 548 to $574{ }^{\circ} \mathrm{C}$ for sample comprising $16 \mathrm{~mol} \% \mathrm{CaO}$ and decreases up to $539^{\circ} \mathrm{C}$ for $32 \mathrm{~mol} \mathrm{\%} \mathrm{CaO}$ [17]. The increase of $\mathrm{MgO}$ content at the expense of $\mathrm{Fe}_{2} \mathrm{O}_{3}$ results in alteration in $T_{\mathrm{g}}$ value from $499{ }^{\circ} \mathrm{C}$ to $545{ }^{\circ} \mathrm{C}$ in the $(40-x) \mathrm{MgO}-x \mathrm{Fe}_{2} \mathrm{O}_{3}-60 \mathrm{P}_{2} \mathrm{O}_{5}$ series [18].

In the ternary glasses, the influence of mentioned components on glass transition temperature is varied. The present study allows to shed light on this matter in far more complex $\mathrm{P}_{2} \mathrm{O}_{5}-\mathrm{SiO}_{2}-\mathrm{K}_{2} \mathrm{O}-\mathrm{MgO}-\mathrm{CaO}-\mathrm{Fe}_{2} \mathrm{O}_{3}$ system. $T_{\mathrm{g}}$ variability was revealed by means of DSC. Moreover, Diffused Reflectance Fourier Transform Infrared Spectroscopy was used to determine the structural changes within the glass transition effect and simultaneously the response of the structure to thermal treatment was registered. The influence of chemical composition on the structure was also analyzed via Fourier transform infrared spectroscopy. Density measurements were carried out in order to establish a precise connection with physical properties and supported the interpretation of thermal and structural studies.

\section{Experimental}

The description of preparation of glasses from $\mathrm{P}_{2} \mathrm{O}_{5}-\mathrm{SiO}_{2}-$ $\mathrm{K}_{2} \mathrm{O}-\mathrm{MgO}-\mathrm{CaO}-\mathrm{Fe}_{2} \mathrm{O}_{3}$ system with quantitative proportion of $\mathrm{P}_{2} \mathrm{O}_{5}: \mathrm{SiO}_{2}: \mathrm{K}_{2} \mathrm{O}$ and $\mathrm{MgO}: \mathrm{CaO}$ set as 41:6:6 and 1.5:1 was included in the study presented in [19]. Chemical composition is expressed by $\mathrm{Fe} /(\mathrm{Fe}+\mathrm{Ca}+\mathrm{Mg})$ ratio (Table 1), as only the content of iron, magnesium and calcium ions is varied. It needs to be noted that the notation of each glass contains information about the amount of incorporated iron oxide. For example, 2Fe41P means the $2 \mathrm{~mol} \% \mathrm{Fe}_{2} \mathrm{O}_{3}$ addition.

Thermal stability of the obtained glasses was determined by DSC measurements conducted on Netzsch STA 449 F3 Jupiter 7 operating in the heat flux DSC mode. The temperature and heat calibrations of the instrument were performed using the melting temperatures and melting enthalpies of high-purity materials (Al, $\mathrm{Zn}, \mathrm{Sn}, \mathrm{Au}, \mathrm{Ag}$ ). The samples $(45 \mathrm{mg}$ ) were heated in platinum crucibles at $10{ }^{\circ} \mathrm{C} \mathrm{min}{ }^{-1}$ in air atmosphere up to $600{ }^{\circ} \mathrm{C}$. The glass transformation temperature $T_{\mathrm{g}}$ determined as the midpoint
Table 1 Correlation of alteration in chemical compositions, physical properties and thermal parameters in glasses from $\mathrm{P}_{2} \mathrm{O}_{5}-\mathrm{SiO}_{2}-\mathrm{K}_{2} \mathrm{O}-$ $\mathrm{MgO}-\mathrm{CaO}-\mathrm{Fe}_{2} \mathrm{O}_{3}$ system

\begin{tabular}{|c|c|c|c|c|}
\hline & $2 \mathrm{Fe} 41 \mathrm{P}$ & $8 \mathrm{Fe} 41 \mathrm{P}$ & $15 \mathrm{Fe} 41 \mathrm{P}$ & $30 \mathrm{Fe} 41 \mathrm{P}$ \\
\hline $\mathrm{O} / \mathrm{P}$ & 3.3 & 3.5 & 3.7 & 4.0 \\
\hline $\mathrm{Fe} /(\mathrm{Fe}+\mathrm{Ca}+\mathrm{Mg})$ & 0.09 & 0.30 & 0.49 & 0.78 \\
\hline $\mathrm{Fe}^{2+} / \mathrm{Fe}_{\text {total }}[19]$ & 0.66 & 0.34 & 0.30 & 0.15 \\
\hline$T_{\mathrm{g} \text { onset }} /{ }^{\circ} \mathrm{C}$ & 501 & 500 & 512 & 520 \\
\hline$T_{\mathrm{g}} /{ }^{\circ} \mathrm{C}$ & 512 & 514 & 524 & 528 \\
\hline$T_{\mathrm{g} \text { endset }} /{ }^{\circ} \mathrm{C}$ & 522 & 528 & 536 & 536 \\
\hline$\Delta c_{\mathrm{p}} / \mathrm{J} \mathrm{g}^{-1} \mathrm{~K}^{-1}$ & 0.25 & 0.25 & 0.26 & 0.28 \\
\hline$\tau / \min$ & 2.1 & 2.8 & 2.4 & 1.6 \\
\hline$d_{\mathrm{r}} / \mathrm{g} \mathrm{cm}^{-3}$ & 2.59 & 2.78 & 2.89 & 3.06 \\
\hline$V_{\mathrm{mol}} / \mathrm{cm}^{3} \mathrm{~mol}^{-1}$ & 35.37 & 35.39 & 36.78 & 40.28 \\
\hline$d_{\mathrm{o}} / \mathrm{g} \mathrm{cm}^{-3}$ & 1.24 & 1.29 & 1.30 & 1.31 \\
\hline
\end{tabular}

of the $c_{\mathrm{p}}$ changes in the glass transformation region and changes in specific heat $\left(\Delta c_{\mathrm{p}}\right)$ accompanying the glass transformation was determined by applying the Netzsch Proteus Thermal Analysis Program (version 5.0.0.).

Density of the samples was measured by helium pycnometry technique using Micromeritics AccuPyc II 1340 Gas Pycnometer apparatus. In this apparatus, helium is pumped to the chamber with the sample, until certain pressure is reached (in this case, $19.50 \mathrm{psi}=1.37 \mathrm{~atm}$ ). Then, the gas from the chamber with the sample is pumped to another chamber, where its pressure is measured. The volume of the sample is calculated basing on the differences in the pressure of the gas in the both chambers using ideal gas law (helium can be treated as the ideal gas). Knowing volume of the sample and its mass, which is determined before the measurement with an accuracy of $0.0001 \mathrm{~g}$, software is calculating the density of the sample with an accuracy up to $0.0001 \mathrm{~g} \mathrm{~cm}^{-3}$. Measurement was repeated 30 times to ensure precision. Before the measurement, the sample was purged with helium 70 times to remove impurities and stabilize its temperature andwhich implies_-volume.

FTIR spectra were collected in room temperature using a Bruker Company Vertex 70v spectrometer in the range of $1400-400 \mathrm{~cm}^{-1} .128$ scans at the $4 \mathrm{~cm}^{-1}$ resolution were accumulated. Standard $\mathrm{KBr}$ pellet method was used in sample preparation. The amount of $\mathrm{KBr}$ and appropriately grinded fraction of glass were accurately weighed.

High temperature DRIFTS (Diffused Reflectance Fourier Transform Infrared Spectroscopy) measurements were performed using Bruker Vertex 70v spectrometer equipped with Harrick Scientific "Praying Mantis" DRS attachment and high temperature reaction chamber with $\mathrm{KBr}$ windows (HVC-DRP-5). A total of 128 scans were accumulated in 
the range of $4000-400 \mathrm{~cm}^{-1}$. Scanner velocity was set to $5 \mathrm{kHz}$ along with $4 \mathrm{~cm}^{-1}$ resolution. Each measurement was carried out after $5 \mathrm{~min}$ of temperature stabilization.

\section{Fourier transform infrared spectroscopy results obtained at ambient temperature}

Figure 1 presents spectra of glasses containing 2, 4, 8, 15 and $30 \mathrm{~mol} \% \mathrm{Fe}_{2} \mathrm{O}_{3}$ recorded at room temperature. Bands have been revealed in the $1400-1200 \mathrm{~cm}^{-1}$, $1200-850 \mathrm{~cm}^{-1}, 850-650 \mathrm{~cm}^{-1}, 650-400 \mathrm{~cm}^{-1}$ regions and their assignment is performed.

\section{$1400-1200 \mathrm{~cm}^{-1}$}

Distinct band at $1281 \mathrm{~cm}^{-1}$ is observed for $2 \mathrm{Fe} 41 \mathrm{P}$ glass. Progressive substitution of $\mathrm{CaO}$ and $\mathrm{MgO}$ by $\mathrm{Fe}_{2} \mathrm{O}_{3}$, manifested also in alterations of $\mathrm{Fe} /(\mathrm{Fe}+\mathrm{Ca}+\mathrm{Mg})$ ratio within the range from 0.087 up to 0.782 , is associated with the shift of its location to lower wavenumber. Moreover, in $15 \mathrm{Fe} 41 \mathrm{P}$ and $30 \mathrm{Fe} 41 \mathrm{P}$ glasses its separateness is significantly more influenced. It may be assigned to asymmetric stretching vibrations of two non-bridging oxygen atoms bonded to phosphorus atoms $\mathrm{O}-\mathrm{P}-\mathrm{O}$ in $\mathrm{PO}_{2}{ }^{-}$groups in metaphosphate units $[16,20-22]$. The aforementioned

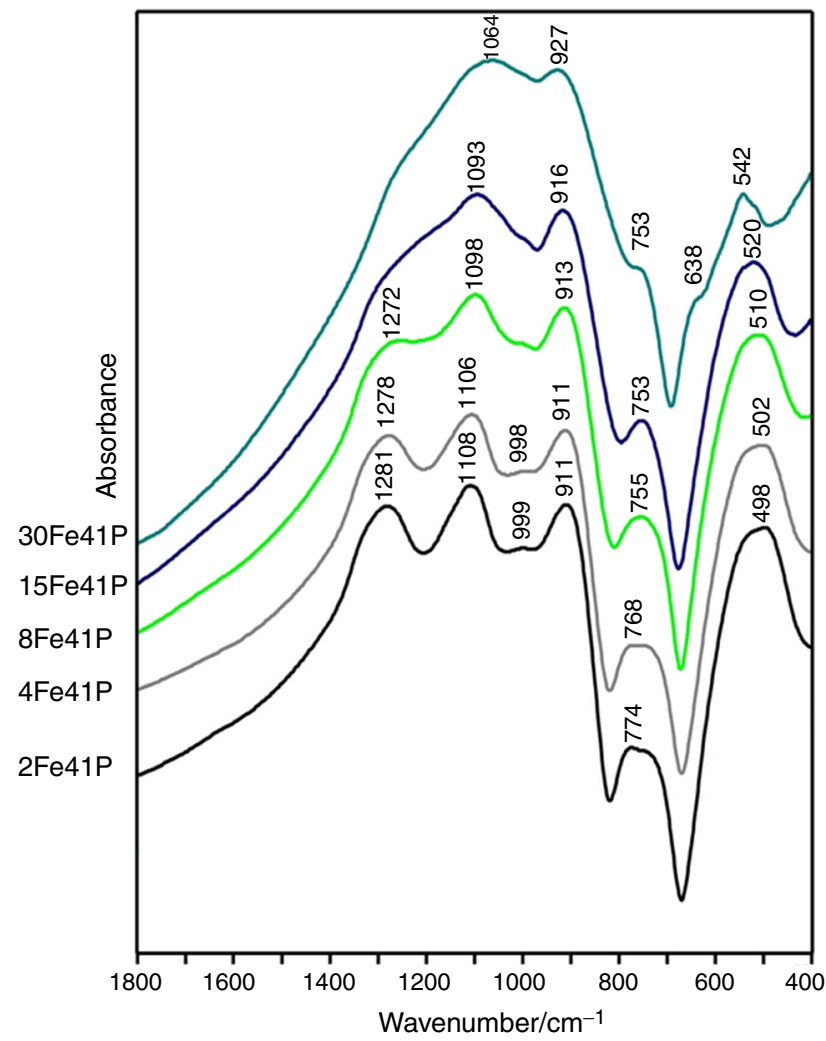

Fig. 1 Infrared spectra of studied glasses collected in room temperature variation confirms the depolymerizing role of $\mathrm{Fe}_{2} \mathrm{O}_{3}$ on the phosphorus-oxygen subnetwork concluded from Raman study [19].

\section{$1200-950 \mathrm{~cm}^{-1}$}

Spectrum of glass with 2 mol\% iron oxide addition is characterized by pronounced band at $1108 \mathrm{~cm}^{-1}$ and minor band at $999 \mathrm{~cm}^{-1}$. Concomitantly, with increase of $\mathrm{Fe} /$ $(\mathrm{Fe}+\mathrm{Ca}+\mathrm{Mg})$ ratio the visible broadening is detected, mainly the band localized at higher wavenumbers $\left(1108 \mathrm{~cm}^{-1} \rightarrow 1064 \mathrm{~cm}^{-1}\right)$ are affected.

According to [23], band at about $1100 \mathrm{~cm}^{-1}$ corresponds to the combination of $\mathrm{P}-\mathrm{O}$ and $\mathrm{Si}-\mathrm{O}$ stretching vibration in $\mathrm{P}-\mathrm{O}-\mathrm{P}$ and $\mathrm{P}-\mathrm{O}-\mathrm{Si}$ linkages in metaphosphate units. Following Hudgens and Martin [24], it may be also assigned to the symmetric stretching of $\mathrm{PO}_{2}$ groups. It shifts to lower wavenumbers with increase of $\mathrm{Fe} /(\mathrm{Fe}+$ $\mathrm{CaO}+\mathrm{MgO}$ ) ratio. Observed alteration in analyzed spectra of iron phosphate-silicate glasses are considered as advanced, what is apparently connected to the strong effect of ferrous and ferric ions especially on phosphorus-oxygen subnetwork, indicated also in [25]. Thus, spectra of $15 \mathrm{Fe} 41 \mathrm{P}$ and $30 \mathrm{Fe} 41 \mathrm{P}$ glasses are characterized by broaden bands with maximum designated at $1093 \mathrm{~cm}^{-1}$ and $1064 \mathrm{~cm}^{-1}$. The first one may be attributed to asymmetric stretching vibrations $v_{\mathrm{as}}\left(\mathrm{P}_{2} \mathrm{O}_{7}\right)^{4-}$ in pyrophosphate units $[26,27]$. It is consistent with results obtained from analysis of Raman spectrum of 15Fe41P [19]. The second one may be a corollary of $\left(\mathrm{PO}_{4}\right)^{3-}$ asymmetric stretching in orthophosphate units $[21,28,29]$. Although the assignment of the band observed in spectrum of $2 \mathrm{Fe} 41 \mathrm{P}$ is not definite, the tendency to the network depolymerization is once again revealed.

Bands at about $999 \mathrm{~cm}^{-1}$ are connected to asymmetric [23] or symmetric [16] stretching vibrations in metaphosphate units [23], particularly $\mathrm{P}-\mathrm{O}$ bonds in the $\left(\mathrm{PO}_{3}\right)^{2-}$ end chain groups are implied to be involved [22,30]. Corbridge and Lowe [29] indicated the presence of band located in similar position (approx. $1000 \mathrm{~cm}^{-1}$ ) as a distinguishing feature of cyclic metaphosphate compounds.

Another possible interpretation of band at about $999 \mathrm{~cm}^{-1}$ is the asymmetric stretching of $\left(\mathrm{PO}_{4}\right)^{3-}$ anions [31]. It would indicate that in $2 \mathrm{Fe} 41 \mathrm{P}$ glass certain amount of isolated phosphate polyhedra is present. These comparatively inconspicuous bands seem to be increasing with gradual iron oxide addition.

\section{$950-650 \mathrm{~cm}^{-1}$}

The bands in aforementioned region are generally connected to asymmetric and symmetric stretching vibrations of $\mathrm{P}-\mathrm{O}-\mathrm{P}$ linkages $[29,32]$ in phosphate glasses. The 
conspicuous upshift observed in the $850-950 \mathrm{~cm}^{-1}$ region is presumably associated with decreasing length of the $\mathrm{P}-$ O-P chain [29]. Therefore, due to position at $927 \mathrm{~cm}^{-1}$, the structure of $30 \mathrm{Fe} 41 \mathrm{P}$ is characterized by shorter chains and increased number of pyrophosphate units [26, 28, 33]. Simultaneously in $2 \mathrm{Fe} 41 \mathrm{P}$ glass, the band at $911 \mathrm{~cm}^{-1}$ indicate that increased number of $\mathrm{P}-\mathrm{O}-\mathrm{P}$ linkages compared to $30 \mathrm{Fe} 41 \mathrm{P}$ glass are revealed, and it is another confirmation of the mainly depolymerizing role manifested by iron ions.

Bands located at lower frequencies in this region may be connected to vibrations occurring in linear chains, cyclic metaphosphates and also pyrophosphate links. Glasses with lower iron oxide addition are characterized by broaden band between 774 and $700 \mathrm{~cm}^{-1}$. This absorption bands may be also connected to links in cyclic metaphosphates [29], such as $\left(\mathrm{P}_{2} \mathrm{O}_{6}\right)^{2-}$ which are characterized by two $\mathrm{P}-$ $\mathrm{O}-\mathrm{P}$ linkages [22]. More sharp band at $753 \mathrm{~cm}^{-1}$ is more likely to be corresponding to pyrophosphate units $\left(\mathrm{P}_{2} \mathrm{O}_{7}\right)^{4-}$ within the single $\mathrm{P}-\mathrm{O}-\mathrm{P}$ linkage [22, 33]. Such behavior presented in this region is another proof of gradual distortion of the structure. It is in agreement with interpretation presented in [30] dedicated to the study of vanadium barium phosphate glasses which exhibit a similar behavior.

\section{$650-400 \mathrm{~cm}^{-1}$}

The low frequency band in the $490-520 \mathrm{~cm}^{-1}$ region is presumably connected to harmonics of bending vibration of $\mathrm{O}=\mathrm{P}-\mathrm{O}$ linkages [32]. It may be also a manifestation of combination of bending vibrations of $\mathrm{O}-\mathrm{Si}-\mathrm{O}$ and $\mathrm{O}-\mathrm{P}-\mathrm{O}$ bonds [23].

Simultaneously, band at $638 \mathrm{~cm}^{-1}$ observed in spectrum of $30 \mathrm{Fe} 41 \mathrm{P}$ is located in the characteristic region in MIR spectra of crystalline $\mathrm{Fe}_{2} \mathrm{O}_{3}[34,35]$. It was pointed out that vibration of $\mathrm{Fe}-\mathrm{O}$ may be reflected more clearly on the spectra below $300 \mathrm{~cm}^{-1}$ [32], particularly at $230 \mathrm{~cm}^{-1}$ for ferrous and $290 \mathrm{~cm}^{-1}$ for ferric ions. It is also possible, that bands which are due to $\mathrm{Fe}-\mathrm{O}$ are masked or superimposed with vibration of $\mathrm{O}=\mathrm{P}-\mathrm{O}$ linkages [35]. Nevertheless, a spectrum of $30 \mathrm{Fe} 41 \mathrm{P}$ glass is quite distinctive. The conspicuous band at $542 \mathrm{~cm}^{-1}$ may be also connected to O-P$\mathrm{O}$ bending vibrations particularly in pyrophosphate structure [36]. The band at $638 \mathrm{~cm}^{-1}$ may be also the effect of vibrations of $\mathrm{Fe}-\mathrm{O}-\mathrm{P}$ bond [36].

\section{Thermal and physical properties}

Thermal effects were characterized through assignation of glass transition temperature $\left(T_{\mathrm{g}}\right)$ and change of specific heat $\left(\Delta c_{\mathrm{p}}\right)$. Relaxation time ( $\tau$ was calculated accordingly to Eq. 1 [37]. Impact of increase of iron ions was manifested in noted changes of $T_{\mathrm{g}}$ and $\Delta c_{\mathrm{p}}$ values designated from DSC curves (Fig. 2) and in density, molar volume and oxygen packing density. The set of parameters is presented in Table 1.

$\tau=\frac{T_{\mathrm{g} \text { endset }}-T_{\mathrm{g} \text { onset }}}{\beta}$

where $\beta$ equals to $10^{\circ} \mathrm{min}^{-1}$ - the heating rate.

Glass transition temperature $\left(T_{\mathrm{g}}\right)$ is slightly increasing. This effect is strongly depended on the substitution of ions marked in $\mathrm{Fe} /(\mathrm{Fe}+\mathrm{Ca}+\mathrm{Mg})$ value, and depolymerization degree commonly reflected in $\mathrm{O} / \mathrm{P}$ ratio.

The general tendency of bands assigned to non-bridging links in various structural phosphate units to downshift, registered particularly in Raman and also in MIR spectra shows that in case of phosphorus-oxygen subnetwork the number of relatively longer and less covalent bonds comparing to bridging bonds in phosphate chain is increasing. Considering the confirmed gradual depolymerization, it can be assumed that progressive shortening of chains leads to massive disruption in the structure. Following [24, 38], it would imply the tendency of $T_{\mathrm{g}}$ to decrease.

Glass transition temperature $\left(T_{\mathrm{g}}\right)$ depends on chemical composition and the type of incorporated cations has also a strong impact which cannot be omitted [24]. Progressive substitution of magnesium and calcium oxide with iron oxide leads to the increasing of the number of bonds in which iron ions are involved. The previous work [19] also indicated that simultaneously the number of coordinated both tetra and octahedrally $\mathrm{Fe}^{3+}$ ions is increasing above decreasing of $\mathrm{Fe}^{2+}$ ions in this system.

Thus, a slight increase of $T_{\mathrm{g}}$ value may be rather explained through the differences in cation field strength [38]. The exact values of $Z / a^{2}$ parameter ( $Z$ - valence, $a$ ionic distance for oxides $[\AA]$ ) are equal to 0.76 for $\mathrm{Fe}^{3+}$ in octahedral and 0.85 in tetrahedral coordination which is vividly increased compared to the values for magnesium ( 0.45 in octahedral coordination), calcium ( 0.33$)$ and even octahedrally coordinated ferrous $(0.43)$ ions $[38,39]$.

Cations characterized by smaller size and greater charge density such as ferric ions are connected with phosphate anions through oxygen atoms and create bonds stronger than formed by calcium and magnesium ions, and theoretically make the structure more rigid. It also enlarges the required temperature of rotational activation modes $[24,38]$ and reinforces the structure. It is connected with the increase of $T_{\mathrm{g}}$ value (Fig. 3a), the most significant for $8 \mathrm{Fe} 41 \mathrm{P}$ and $15 \mathrm{Fe} 41 \mathrm{P}$ glasses. It is also consistent with the statement which confirms that the obtained alteration in $T_{\mathrm{g}}$ value are a consequence of strengthening of the structure [36].

A studied metaphosphate glass $2 \mathrm{Fe} 41 \mathrm{P}$ contains more magnesium and calcium ions and simultaneously possesses more $\mathrm{P}-\mathrm{O}-\mathrm{P}$ joints and $\mathrm{Mg}-\mathrm{O}$ and $\mathrm{Ca}-\mathrm{O}$ bonds. It changes 
Fig. 2 DSC curves of iron phosphate-silicate glasses collected in temperature range $250-600{ }^{\circ} \mathrm{C}$ with a designation of glass transition temperature effect

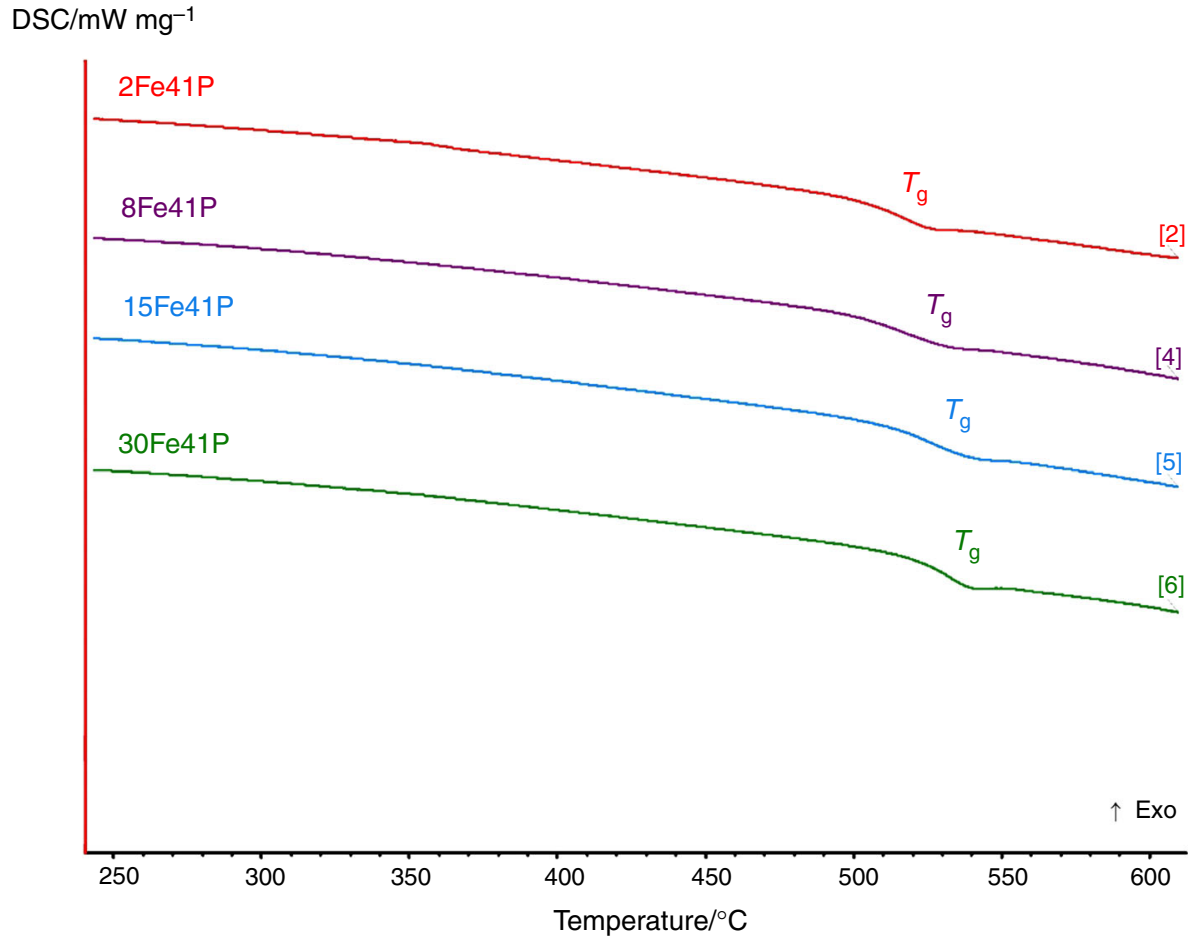

with the increase of $\mathrm{Fe} /(\mathrm{Fe}+\mathrm{Ca}+\mathrm{Mg})$ parameter which reflects the degree of the substitution of particular ions. Both magnesium and calcium oxygen bonds are less covalent $\left(i_{\mathrm{G}} \quad \mathrm{Mg}-\mathrm{O}=0.670\right.$ and $\left.i_{\mathrm{G}} \quad \mathrm{Ca}-\mathrm{O}=0.707\right) \quad$ [40] comparing to $\mathrm{Fe}^{2+}-\mathrm{O}$ and $\mathrm{Fe}^{3+}-\mathrm{O}\left(i_{\mathrm{GFe}^{2+}-\mathrm{O}}=0.658\right.$ and $i_{\mathrm{GFe}^{3+}{ }_{-\mathrm{O}}}=0.529$ ) [40], but these values are still tremendously enlarged in comparison to $\mathrm{P}-\mathrm{O}$ bond $\left(i_{\mathrm{G}} \mathrm{P}-\mathrm{O}-\right.$ $=0.314$ ) [40]. Therefore, this glass is made of more polymerized units which are based on more covalent $\mathrm{P}-\mathrm{O}-$ $\mathrm{P}$ linkages, modified by significant ionic influence of $\mathrm{Mg}^{2+}$ and $\mathrm{Ca}^{2+}$. Such differentiation causes a certain internal strains in the structure.

It is presumable that the structure of glasses with higher iron oxide addition is reoriented in order to be strengthen and better preserved, thus $\mathrm{Fe}^{3+}$ ions reinforce more depolymerized structure containing significantly shorter chains, dimers and isolated orthophosphates. In all likelihood, iron ions are involved in formation of more ionic and therefore more elastic, however, still adequately strong bonds comparing to $\mathrm{P}-\mathrm{O}-\mathrm{P}$ bridging linkages reduced along with increase of $\mathrm{Fe} /(\mathrm{Fe}+\mathrm{Ca}+\mathrm{Mg})$ ratio.

Set of parameters used for the description of physical properties of studied glasses, such as molar volume $V_{\text {mol }}$ and oxygen packing density $d_{\mathrm{o}}$ calculated from Eqs. 2 and 3 [41], and measured density $d_{\mathrm{r}}$ is presented in Table 1. Mentioned parameters increase with gradual iron oxide addition (Fig. 3b-d).
$V_{\mathrm{mol}}=\left(\sum_{\mathrm{MO}} x_{\mathrm{MO}} M_{\mathrm{MO}}\right) d_{\mathrm{r}}^{-1}$

Where $x_{\mathrm{MO}}$ is the molar fraction and $M_{\mathrm{MO}}$ is the molecular weight of the particular oxide, and $d_{\mathrm{r}}$ is experimentally determined density.

$d_{\mathrm{o}}=m_{\mathrm{o}} V_{\mathrm{mol}}^{-1}$

Where $m_{\mathrm{o}}$ is mass of oxygen atoms in one mole of glass.

The variation of density is due to substitution of ions with smaller atomic weight which are in this case calcium and magnesium ions, by iron ions with higher molecular mass. Such implication makes structure more dense.

Concomitantly, as can be seen in Table 1, the molar volume increases along with $\mathrm{Fe} /(\mathrm{Fe}+\mathrm{Ca}+\mathrm{Mg})$ ratio and reduce of $\mathrm{Fe}^{2+} / \mathrm{Fe}_{\text {total }}$ ratio. It designates that the structure is more expanded and it correlates with increase of not only the number of non-bridging oxygens [21] but also the number of ferric ions concluded in [19]. Iron redox equilibria impacts the amount of oxygen in the glass. The predominance of ferric ions indicates increase of the number of oxygen atoms [27] which considerably contribute to the volume of the oxygen polyhedral.

Molar volume and oxygen packing density depict the rigidity and compactness in the glass structure [42]. The observed increase of $d_{o}$ value implies the higher mass of oxygen atoms per one mole of glass. It can be also concluded that with incorporation of $\mathrm{Fe}_{2} \mathrm{O}_{3}$, the structure is more packed. It presumably decreases to a certain point the 

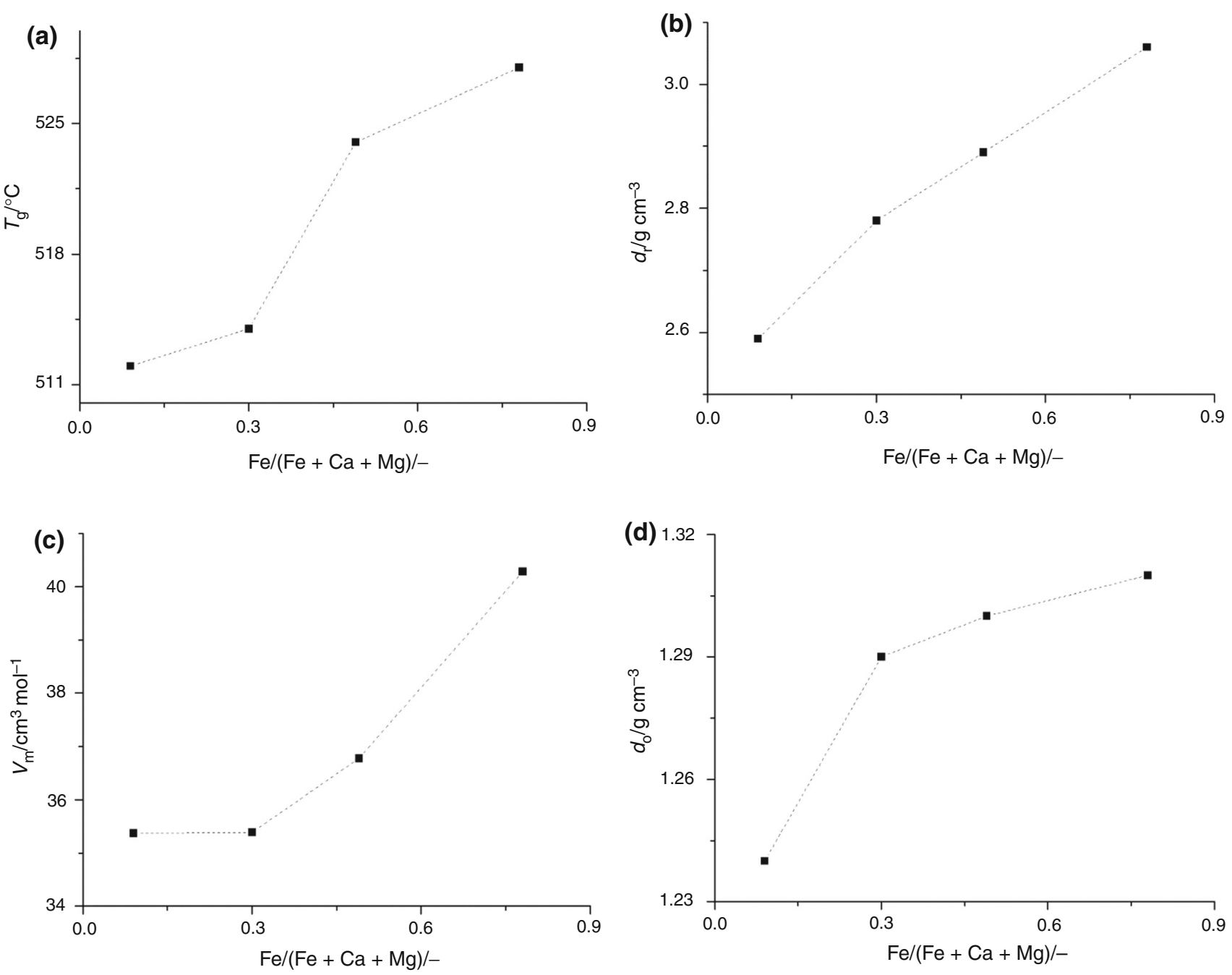

Fig. 3 Structural dependence of glass transition temperature (a), density (b), molar volume (c) and oxygen packing density (d) in studied glasses. The points were connected in order to make the tendency more visible for eye

mobility of components and makes it also slightly more rigid. The certain increase in the rigidity may also explain the minor increase of $T_{\mathrm{g}}[43]$.

\section{Results of the spectroscopic study in glass transition temperature range}

Spectra were collected at $T_{\mathrm{g} \text { onset, }} T_{\mathrm{g}}$ and $T_{\mathrm{g}}$ endset temperatures designated via DSC method (Table 1) with preservation of constant heating velocity $\left(10^{\circ} \mathrm{min}^{-1}\right)$ in order to gain information about structural alterations occurring in glasses containing $2 \mathrm{~mol} \%$ and $30 \mathrm{~mol} \% \mathrm{Fe}_{2} \mathrm{O}_{3}$. Obtained results were directly connected with glass transition effects revealed in DSC curves (Figs. 4a, 5a). Spectra before heating and after cooling were also recorded and presented in Figs. $4 b, 5 b$.

\section{Fe41P glass}

As it can be seen in Fig. 4a, the collected spectra of 30Fe41P sample at $T_{\mathrm{g} \text { onset }}, T_{\mathrm{g}}$ and $T_{\mathrm{g} \text { endset }}$ are varied in a subtle way. Spectra obtained from sample before heating and after cooling are in relatively good agreement. Only a slight rise and shifts in bands positions after cooling is observed.

Glass transition effect demarcates the rigid and viscoelastic states. In glass transition temperature, a weak thermal vibrations are induced. They presumably cause the breaking of bonds characterized by higher ionicity. Above $T_{\mathrm{g}}$, the occurrence of significant change of structurally sensitive properties is also manifested, which is correlated to progressive gradual breaking of oxygen bonds and depolymerization of the network [44].

As it was indicated, iron ions creates less ionic but sufficiently strong bonds, thus the structure exhibits 
(a)

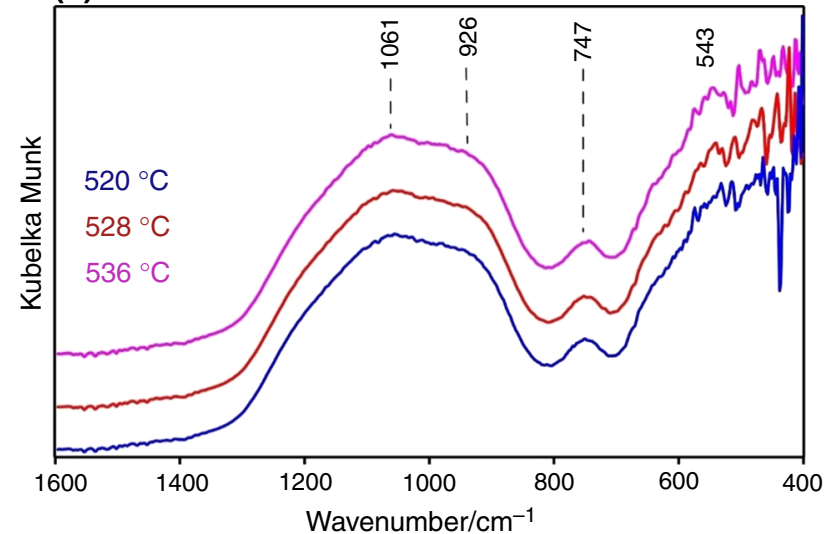

(b)

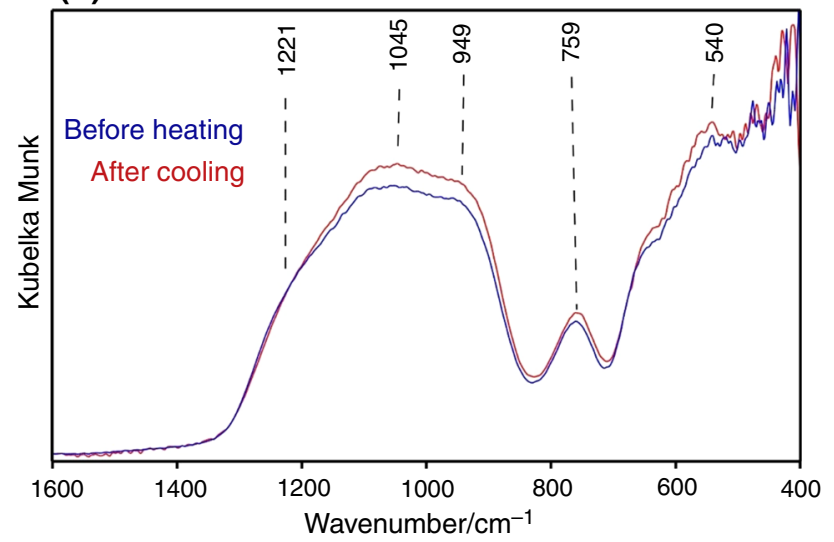

Fig. 4 Results of diffused reflectance Fourier transform infrared spectroscopy measurements of phosphate-silicate glass containing $30 \mathrm{~mol} \%$ iron oxide addition a in temperatures associated with glass transition effect $\mathbf{b}$ before heating and after cooling

essential resistance. Furthermore, it needs to be noted that based on $\mathrm{O} / \mathrm{P}$ value, 30Fe41P should be recalled as a glass with high amount of orthophosphate units. Its Raman and MIR spectra collected in room temperature, however, reveal the existence of $\mathrm{P}-\mathrm{O}-\mathrm{P}$ linkages. Corresponding bands assigned to $\mathrm{P}-\mathrm{O}-\mathrm{P}$ linkages located in the $850-950 \mathrm{~cm}^{-1}$ and $700-800 \mathrm{~cm}^{-1}$ regions are only slightly influenced due to temperature treatment (Fig. 4a). Based on that results, it is stated that alteration in polymerization degree at temperatures associated with glass transition effect is elusive.

Certain shifts are, however, visible in Fig. $4 \mathrm{~b}$ in spectra before heating and after cooling. Changes in location of bands presumably associated with vibrations of bridging oxygens in $Q^{1}$ units and stretches of $\left(\mathrm{PO}_{4}\right)^{3-}$ groups indicate that cooling with velocity rate equal to $10{ }^{\circ} \mathrm{C} \mathrm{min}^{-1}$ was sufficient to obtain the material containing only slightly more orthophosphate and pyrophosphate units than the starting one. Nevertheless, the detected structural (a)

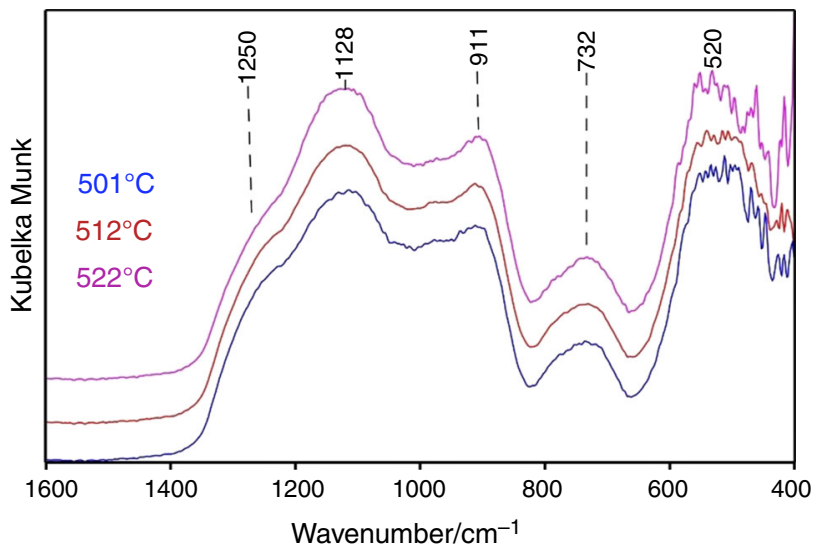

(b)

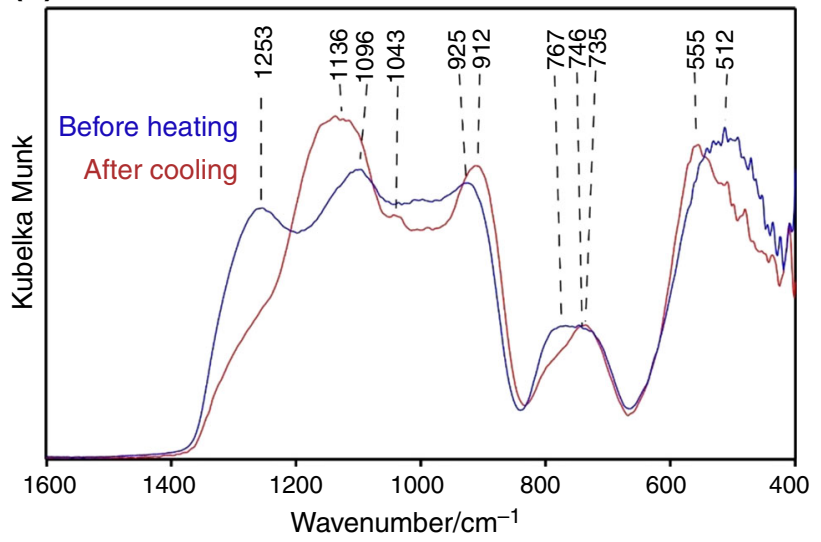

Fig. 5 Results of diffused reflectance Fourier transform infrared spectroscopy measurements of phosphate-silicate glass containing $2 \mathrm{~mol} \%$ iron oxide addition a in temperatures associated with glass transition effect $\mathbf{b}$ before heating and after cooling

alterations in case of this sample occurring due to glass transition effect are relatively minor.

\section{Fe41P glass}

On the contrary to $30 \mathrm{Fe} 41 \mathrm{P}$ glass, in spectra collected from $2 \mathrm{Fe} 41 \mathrm{P}$ glass alterations are more visible and it presumably entails more modifications in the structure (Fig. 5a). Observed changes are listed below:

- band assigned to asymmetric stretch in $\left(\mathrm{PO}_{2}\right)^{-}$groups is becoming to be less distinct.

- band in the region $1150-1050 \mathrm{~cm}^{-1}$ is broadening and increasing.

- Band located in the region $950-850 \mathrm{~cm}^{-1}$ shifts slightly to higher wavenumbers.

- Band in $800-650 \mathrm{~cm}^{-1}$ region exhibits the change in shape

Alterations observed in $950-650 \mathrm{~cm}^{-1}$ region similarly as it was in case of $30 \mathrm{Fe} 41 \mathrm{P}$ indicate the increase of the 
number of shorter chains, pyrophosphate units. Moreover, a decrease of the amount of metaphosphate units may be also concluded from the behavior of band at $\sim 1250 \mathrm{~cm}^{-1}$.

Simultaneously, the band at about $1128 \mathrm{~cm}^{-1}$ is rising. In this region, stretching vibrations of non-bridging oxygen links in various phosphate groups are observed. This band should be presumably connected to the band at about $1100 \mathrm{~cm}^{-1}$ observed in spectra obtained in ambient temperature (Fig. 1). The slight change in the area under band may indicate the alterations of the amount of $\mathrm{P}-\mathrm{O}$ and $\mathrm{Si}-\mathrm{O}$ bonds and fluctuations of the number of $Q^{2}$ and $Q^{1}$ units.

As it was indicated through changes of oxygen packing density, molar volume and glass transition temperature, structure of $2 \mathrm{Fe} 41 \mathrm{P}$ in its parent state is less dense and packed, contains more ionic $\mathrm{Ca}-\mathrm{O}$ and $\mathrm{Mg}-\mathrm{O}$ bonds and is characterized by more polymerized network. It is presumable that it possesses more flexibility. Nevertheless, value of obtained relaxation time for $2 \mathrm{Fe} 41 \mathrm{P}$ glass is higher than for $30 \mathrm{Fe} 41 \mathrm{P}$ glass.

As can be seen in Fig. 5b, spectra before heating and after cooling differ considerably. The states obtained after cooling (Fig. 5b) and observed within the glass transition effect presented in Fig. 5a are found to be relatively similar. It implies a good preservation of the structure received in glass transition temperatures ranges. It also indicates that in contradiction to $30 \mathrm{Fe} 41 \mathrm{P}$ glass, alterations in $2 \mathrm{Fe} 41 \mathrm{P}$ glass spectra are far more progressive.

\section{Conclusions}

Results obtained in MIR study at room temperature confirmed that materials with lower iron oxide addition are more polymerized. This statement was concluded through deliberations about the changes in the $1300-1050 \mathrm{~cm}^{-1}$ and $950-650 \mathrm{~cm}^{-1}$ regions corresponded with vibrations of non-bridging oxygens and stretches of $\mathrm{P}-\mathrm{O}-\mathrm{P}$ linkages.

Alterations in thermal properties detected in glasses from $\mathrm{P}_{2} \mathrm{O}_{5}-\mathrm{SiO}_{2}-\mathrm{K}_{2} \mathrm{O}-\mathrm{MgO}-\mathrm{CaO}-\mathrm{Fe}_{2} \mathrm{O}_{3}$ system are considerably minor. A slight augmentation of $T_{\mathrm{g}}$ and $\Delta c_{\mathrm{p}}$ values with incorporation of $\mathrm{Fe}_{2} \mathrm{O}_{3}$ is explained by greater field strength of ferric ions. Glass transition effect is influenced by many factors and exhibits high complexity. Present work states that the degree of polymerization and the relations between glass components concluded from bonds ionicity needs to be also taken in considerations.

Displayed tendency of physical properties confirmed the impact of variations of chemical composition on the structure of studied materials. Glasses with higher iron oxide addition are more dense and packed. However, it does not entail the decrease in molar volume, what marks the expansion of the structure.
Designated value of time relaxation $(\tau)$ occurred to be higher for more polymerized $2 \mathrm{Fe} 41 \mathrm{P}$ glass. It was concluded from DRIFT spectra collected in temperature ranges attributed with glass transition effect that the alterations in the structure are more significant in this sample in comparison to detected modifications in $30 \mathrm{Fe} 41 \mathrm{P}$. The response to thermal treatment was also pronounced and revealed through comparison of spectra obtained before heating and after cooling. 2Fe41P sample is found to be less resistant than $30 \mathrm{Fe} 41 \mathrm{P}$ glass.

Due to smaller alterations in $30 \mathrm{Fe} 41 \mathrm{P}$ glass revealed via diffused reflectance Fourier transform infrared spectroscopy, it may be assumed that iron oxide addition makes the glass more resistant in designated temperature range. It is presumably also associated with the reduced number of more ionic $\mathrm{Ca}-\mathrm{O}$ and $\mathrm{Mg}-\mathrm{O}$ bonds.

The $30 \mathrm{Fe} 41 \mathrm{P}$ sample is more resistant to thermal treatment in designated temperature range. It is presumable that the ferric ions incorporation leads to the reinforcement of the structure of iron pyrophosphate glass from $\mathrm{P}_{2} \mathrm{O}_{5}-\mathrm{SiO}_{2}-$ $\mathrm{K}_{2} \mathrm{O}-\mathrm{MgO}-\mathrm{CaO}-\mathrm{Fe}_{2} \mathrm{O}_{3}$ system.

Acknowledgements The work was supported by the Faculty of Materials Science and Ceramics AGH-University of Science and Technology No. 11.11.160.617 and the EU Project POWR.03.02.0000-I004/16.

Open Access This article is distributed under the terms of the Creative Commons Attribution 4.0 International License (http://creative commons.org/licenses/by/4.0/), which permits unrestricted use, distribution, and reproduction in any medium, provided you give appropriate credit to the original author(s) and the source, provide a link to the Creative Commons license, and indicate if changes were made.

\section{References}

1. Sales BC. Phosphate glasses. Mater Res Soc. 1987;12:32-4.

2. Yin Q, Kang S, Wang X, Li S, He D, Hu L. Effect of PbO on the spectral and thermo-optical properties of $\mathrm{Nd}^{3+}$-doped phosphate laser glass. Opt Mater. 2017;66:23-8.

3. Pisarski WA, Żur L, Goryczka T, Sołtys M, Pisarska J. Structure and spectroscopy of rare earth-doped lead phosphate glasses. J Alloys Compd. 2014;587:90-8.

4. Podniesiński D, Nakielska M, Kozłowska A, Stępień R, Pysz D. Laser na szkle fosforanowym domieszkowanym erbem, iterbem i chromem. Electron Mater. 2015;43(1):4-10.

5. Hu L, He D, Chen H, Wang X, Meng T, Wen L, Hu J, Xu Y, Li S, Chen Y, Chen W, Chen S, Tang J, Wang B. Research and development of neodymium phosphate laser glass for high power laser application. Opt Mater. 2017;63:213-20.

6. Stoch P, Stoch A, Ciecińska M, Krakowiak I, Sitarz M. Structure of phosphate and iron-phosphate glasses by DFT calculations and FTIR/Raman spectroscopy. J Non-Cryst Solids. 2016;450:48-60.

7. Ojovan MI, Lee WE. Immobilisation of radioactive waste in glass. In: Ojovan MI, Lee WE, editors. An introduction to nuclear waste immobilisation. 2nd ed. Amsterdam: Elsevier; 2014. p. $245-82$. 
8. Wacławska I, Szumera M. Fosforanowe materiały ceramiczne do immobilizacji kadmu w środowisku glebowym. Ceram Mater. 2011;63(2):407-12.

9. Abou Neel EA, Ahmed I, Pratten J, Nazhat SN, Knowles JC. Characterisation of antibacterial copper releasing degradable phosphate glass fibres. Biomaterials. 2005;26:2247-54.

10. Ahmed I, Shaharuddin SS, Sharmin N, Furniss D, Rudd C. Core/clad phosphate glass fibres containing iron and/or titanium. Biomed Glasses. 2015;1:20-30.

11. Mishra A, Rocherullé J, Massera J. Ag-doped phosphate bioactive glasses: thermal, structural and in vitro dissolution properties. Biomed Glasses. 2016;2:38-48.

12. Yang JH, Park H-S, Cho Y-Z. Silver phosphate glasses for immobilization of radioactive iodine. Ann Nucl Energy. 2017;110:208-14.

13. Brow RK. Review: the structure of simple phosphate glasses. J Non-Cryst Solids. 2000;263\&264:1-28.

14. Bingham PA, Hand RJ, Forder SD. Doping of iron phosphate glasses with $\mathrm{Al}_{2} \mathrm{O}_{3}, \mathrm{SiO}_{2}$ or $\mathrm{B}_{2} \mathrm{O}_{3}$ for improved thermal stability. Mater Res Bull. 2006;41:1622-30.

15. Liebau $F$. The influence of cation properties on the conformation of silicate and phosphate anions. In: Navrotsky A, O'Keeffe M, editors. Structure and bonding in crystals. London: Academic Press, Inc; 1981. p. 198

16. Moustafa YM. Characterization of iron oxychloride potassium phosphate glasses. J Phys D Appl Phys. 1999;32:2278-86.

17. Li H, Wang C, Yu H, Liang X, Yang S. Effects of calcium oxide addition on the structure and thermal properties of iron phosphate glasses. Spectrosc Lett Int J Rapid Commun. 2015;48(3):184-9.

18. Mošner P, Račický A, Koudelka L. Thermal properties and crystallization of $\mathrm{MgO}-\mathrm{FeO}_{\mathrm{x}}-\mathrm{P}_{2} \mathrm{O}_{5}$ glasses. J Therm Anal Calorim. 2018;132(2):843-50.

19. Kuczek J, Jelen P, Stoch P, Błachowski A, Wacławska I, Szumera M. Raman and Mossbauer studies of iron phosphate-silicate glasses. J Mol Struct. 2018;1170:82-9.

20. Liang X, Yin G, Yang S, Lai Y, Wang J. Lanthanum oxide effects on the structure of calcium phosphate glasses. Spectrosc Lett. 2011;44:418-23.

21. Li HJ, Liang XF, Yu HJ, Yang DQ, Yang SY. Studies of structure of calcium-iron phosphate glasses by infrared, Raman and UVVis spectroscopies. Indian J Phys. 2016;90(6):693-8.

22. Shaim A, Et-tabirou M. Role of titanium in sodium titanophosphate glasses and a model of structural units. Mater Chem Phys. 2003;80:63-7.

23. Szumera M, Wacławska I, Sułowska J. Influence of $\mathrm{CuO}$ and $\mathrm{ZnO}$ addition on the multicomponent phosphate glasses: spectroscopic studies. J Mol Struct. 2016;1114:78-83.

24. Hudgens JJ, Martin SW. Glass transition and infrared spectra of low-alkali, anhydrous lithium phosphate glasses. J Am Ceram Soc. 1993;76(7):1691-6.

25. ElBatal FH, Hamdy YM, Marzouk SY. UV-visible and infrared absorption spectra of transition metals-doped lead phosphate glasses and the effect of gamma irradiation. J Non-Cryst Solids. 2009;355:2439-47.
26. Qian B, Liang X, Yang S, He S, Gao L. Effects of lanthanum addition on the structure and properties of iron phosphate glasses. J Mol Struct. 2012;1027:31-5.

27. Fang X, Ray CS, Mogus-Milankovic A, Day DE. Iron redox equilibrium, structure and properties of iron phosphate glasses. J Non-Cryst Solids. 2001;283:162-72.

28. Dube CL, Stennett MC, Gandy AS, Hyatt NC. Simulation of alpha decay of actinides in iron phosphate glasses by ion irradiation. Nucl Instrum Methods Phys Res B. 2016;371:424-8.

29. Corbridge DEC, Lowe EJ. The infra-red spectra of some inorganic phosphorus compounds. J Chem Soc. 1954;1:493-502.

30. Majjane A, Chahine A, Et-tabirou M, Echchahed B, Do T-O, Mc Breen P. X-ray photoelectron spectroscopy (XPS) and FTIR studies of vanadium barium phosphate glasses. Mater Chem Phys. 2014;143:779-87.

31. Efimov AM. IR fundamental spectra and structure of pyrophosphate glasses along the $2 \mathrm{ZnO} \mathrm{P}_{2} \mathrm{O}_{5}-2 \mathrm{Me}_{2} \mathrm{O}_{2} \mathrm{O}_{5}$ join (Me being $\mathrm{Na}$ and Li). J Non-Cryst Solids. 1997;209:209-26.

32. Doweidar H, Moustafa YM, El-Egili K, Abbas I. Infrared spectra of $\mathrm{Fe}_{2} \mathrm{O}_{3}-\mathrm{PbO}-\mathrm{P}_{2} \mathrm{O}_{5}$ glasses. Vib Spectrosc. 2005;37:91-6.

33. Gabelica-Robert $M$, Tarte P. Infrared spectrum of crystalline and glassy pyrophosphates: preservation of the pyrophosphate group in the glassy structure. J Mol Struct. 1982;79:251-4.

34. Mandal S, Hazra S, Ghosh A. Glass formation in the $\mathrm{PbO}-\mathrm{Fe}_{2} \mathrm{O}_{3}$ system with high PbO content. J Mater Sci Lett. 1994;13:1054-5.

35. Moustafa YM, El-Egili K, Doweidar H, Abbas I. Structure and electric conduction of $\mathrm{Fe}_{2} \mathrm{O}_{3}-\mathrm{P}_{2} \mathrm{O}_{5}$ glasses. Phys $\mathrm{B}$. 2004:353:82-91.

36. Lu M, Wang F, Liao Q, Chen K, Qin J, Pan S. FTIR spectra and thermal properties of $\mathrm{TiO}_{2}$-doped iron phosphate glasses. J Mol Struct. 2015;1081:187-92.

37. Sułowska J, Wacławska I, Szumera M. Effect of copper addition on glass transition of silicate-phosphate glasses. J Therm Anal Calorim. 2012;109:705-10.

38. Ma L, Brow RK, Ghussn L, Schlesinger ME. Thermal stability of $\mathrm{Na}_{2} \mathrm{O}-\mathrm{FeO}-\mathrm{Fe}_{2} \mathrm{O}_{3}-\mathrm{P}_{2} \mathrm{O}_{5}$ glasses. J Non-Cryst Solids. 2015;409:131-8.

39. Varshneya AK. Fundamentals of inorganic glasses. London: Academic Press Inc; 1993. p. 35.

40. Görlich E. The effective nuclear charges and the electronegativity. Kraków: Polish Academy of Art and Science; 1997.

41. Fredholm YC, Karpukhina N, Law RV, Hill RG. Strontium containing bioactive glasses: glass structure and physical properties. J Non-Cryst Solids. 2010;356:2546-51.

42. El-Mallawany R. Tellurite glass smart materials: applications in optics and beyond. Berlin: Springer; 2018.

43. El-Mallawany R. Thermal properties and crosslinking of binary $\mathrm{TeO}_{2}-\mathrm{Nb}_{2} \mathrm{O}_{5}$ and $\mathrm{TeO}_{2}-\mathrm{WO}_{3}$ glasses. J Non-Cryst Solids. 2013;379:177-9.

44. Stoch L. Structure and crystallization of multicomponent glasses. In: International Congress on Glass, vol. 1 (2001), p. 62-73.

Publisher's Note Springer Nature remains neutral with regard to jurisdictional claims in published maps and institutional affiliations. 